\title{
Influence of feeding supplements of almond hulls and ensiled citrus pulp on the milk production, milk composition, and methane emissions of dairy cows
}

\author{
S. R. O. Williams, ${ }^{* 1}$ A. V. Chaves, † M. H. Deighton, ${ }^{*}$ J. L. Jacobs, ${ }^{*}$ M. C. Hannah, ${ }^{*}$ B. E. Ribaux, ${ }^{*}$ G. L. Morris, ${ }^{*}$ \\ W. J. Wales, * and P. J. Moate* \\ *Department of Economic Development, Jobs, Transport, and Resources, Agriculture Victoria, Ellinbank, Victoria 3821, Australia \\ †Faculty of Veterinary Science, School of Life Sciences and Environment, The University of Sydney, Sydney, New South Wales, 2006, Australia
}

\begin{abstract}
Almond hulls and citrus pulp have been fed to dairy cows with variable responses for milk production, but no information exists on their effect on enteric methane emissions. This experiment examined the effects of dietary supplementation with either almond hulls or ensiled citrus pulp on the milk yield, milk composition, and enteric methane emissions of dairy cows. Thirtytwo Holstein dairy cows in mid lactation were offered 1 of 3 diets over a 28-d experiment. Twelve cows received a control $(\mathrm{CON})$ diet, 10 cows a diet containing almond hulls (ALH), and 10 cows a diet containing ensiled citrus pulp (CIT). All cows were offered $6.0 \mathrm{~kg}$ of dry matter $(\mathrm{DM}) / \mathrm{d}$ of crushed corn, $2.0 \mathrm{~kg}$ of $\mathrm{DM} / \mathrm{d}$ of cold-pressed canola, and $0.2 \mathrm{~kg}$ of $\mathrm{DM} / \mathrm{d}$ of a mineral mix. In addition, cows fed the CON diet were offered $14.5 \mathrm{~kg}$ of DM/d of alfalfa cubes; cows fed the ALH diet were offered $10.5 \mathrm{~kg}$ of DM/d of alfalfa cubes and 4.0 $\mathrm{kg}$ of DM/d of almond hulls; and cows on the CIT diet were offered $11.5 \mathrm{~kg}$ of $\mathrm{DM} / \mathrm{d}$ of alfalfa cubes and 3.0 $\mathrm{kg}$ of $\mathrm{DM} / \mathrm{d}$ of ensiled citrus pulp. Milk yield was measured daily and milk composition was measured on $4 \mathrm{~d}$ of each week. Individual cow methane emissions were measured by a sulfur hexafluoride tracer technique on d 24 to 28 of the experiment. The mean milk yield of cows fed the CON diet $(27.4 \mathrm{~kg} / \mathrm{d})$ was greater than the mean milk yield of cows fed the ALH diet $(24.6 \mathrm{~kg} / \mathrm{cow}$ per day), whereas the mean milk yield of cows fed the CIT diet $(26.2 \mathrm{~kg} /$ cow per day) was not different from the mean milk yield from cows fed the other 2 diets. Dietary treatment did not influence the concentrations of milk fat, protein, and lactose or fat yields, but the mean protein yield from cows fed the CON diet $(0.87$ $\mathrm{kg} / \mathrm{d}$ ) was greater than that from cows fed the ALH diet $(0.78 \mathrm{~kg} / \mathrm{d})$ but not different to those fed the CIT diet
\end{abstract}

Received July 5, 2017.

Accepted November 15, 2017.

${ }^{1}$ Corresponding author: richard.williams@ecodev.vic.gov.au
$(0.85 \mathrm{~kg} / \mathrm{d})$. In general, we found no differences in the proportion of individual fatty acids in milk. The mean $\mathrm{pH}$ of ruminal fluid from cows offered the CON diet was not different to the $\mathrm{pH}$ in the ruminal fluids of cows offered the ALH or the CIT diets. The mean methane emissions ( $\mathrm{g} / \mathrm{d}$ ) and yields ( $\mathrm{g} / \mathrm{kg}$ of DM intake) were not influenced by dietary treatment. These findings indicate that, although almond hulls and ensiled citrus pulp can be used as a low-cost feed supplement, almond hulls did negatively affect milk production and neither inhibited enteric methane emissions.

Key words: methane yield, cattle, sulfur hexafluoride

\section{INTRODUCTION}

Horticultural by-products can be used as alternative feed supplements for ruminants, especially in times of drought when pasture is not present and traditional feeds, such as pasture hay or alfalfa hay, are scarce or expensive. Almond hulls consist of the outer covering of the almond, but do not include the hard shell. They have been included in the diets of dairy cows (Aguilar et al., 1984; Singer et al., 2008), sheep (Alibés et al., 1983), and goats (Reed and Brown, 1988; Can et al., 2007). Previously observed reductions in DMI when almond hulls have been fed may be due to a shortage of rumen-degradable protein in the diet (Alibés et al., 1983), which could be why a reduction in blood urea concentration has also been reported (Can et al., 2007). However, when almond-hull diets were fortified with nitrogen by the addition of urea, there was no difference in dairy cow performance (Aguilar et al., 1984).

Citrus pulp, consisting of the skin, pulp, and seed residues remaining when citrus fruits are processed for juice, has been fed to dairy cows (e.g.: Belibasakis and Tsirgogianni, 1996; Leiva et al., 2000). Most research has reported no significant difference in milk yield or milk composition between cows fed citrus pulp and a comparative diet (e.g.: Leiva et al., 2000; Gehman et al., 2006). However, several reports have shown cows 
fed citrus pulp produce milk with higher fat concentration compared with cows fed other diets (e.g., van Horn et al., 1975; Belibasakis and Tsirgogianni, 1996). This response in milk fat concentration to the feeding of citrus pulp appears to be related to the concentration of citrus pulp in the diet. In sheep, milk fat concentration was observed to increase with increasing proportions $(0$ to $20 \%$ ) of citrus pulp in the diet, but declined when citrus pulp was fed at $30 \%$ of the diet (Jaramillo et al., 2009).

In addition to their value as dietary supplements, we speculate that both almond hulls and citrus pulp may reduce methane emissions from dairy cows. Almond hulls have been shown to inhibit methane production in vitro, with phenolics, triterpenoids, and antibacterial compounds being identified as possible causes (Durmic et al., 2014). Citrus pulp contains limonene, an essential oil, which has been shown in vitro to have antimethanogenic properties (Kamalak et al., 2011). Thus, we expect that feeding almond hulls and citrus pulp to dairy cows may decrease their methane emissions, with no effect on their milk production or on concentrations of milk fat and milk protein. However, methane yield has been correlated with the fatty acid profile of milk (e.g., Dijkstra et al., 2011), and the fatty acid profile of milk influences the melting point of the milk fat (Jensen and Patton, 2000), which in turn influences the suitability of the milk for the manufacture of dairy products (Hillbrick and Augustin, 2002). If the feeding of almond hulls or citrus pulp does indeed change the amount of methane produced, then we would expect concomitant changes in fatty acid profiles and the melting point of the milk fat.

The aim of our research was to determine the effects of feeding diets containing almond hulls or ensiled citrus pulp to dairy cows on their milk production, milk composition, and methane emissions. We hypothesized that when almond hulls or ensiled citrus pulp replaced alfalfa cubes in the diet of dairy cows we would find (1) no effects on milk production and concentrations of total milk fat and milk protein, (2) a reduction in methane emissions and (3) a change in the fatty acid profile of milk with a commensurate change in the melting point of milk fat.

\section{MATERIALS AND METHODS}

The experiment was conducted at the Department of Economic Development Jobs Transport and Resources, Ellinbank Centre, Victoria, Australia $\left(38^{\circ} 14^{\prime}\right.$ S, $145^{\circ} 56^{\prime}$ E) and was conducted in accordance with the Australian Code of Practice for the Care and Use of Animals for Scientific Purposes (NHMRC, 2004). Animal use was approved by the Animal Ethics Committee of the
Department of Economic Development Jobs Transport and Resources, Victoria.

\section{Experiment Design and Management}

The experiment used 32 lactating, multiparous Holstein-Friesian cows producing $25.2 \pm 2.00 \mathrm{~kg}$ milk/d (mean $\pm \mathrm{SD}$ ), with $614 \pm 57.6 \mathrm{~kg}$ of $\mathrm{BW}$ and 147 \pm 18.2 DIM. We used 3 dietary treatments. First, a control diet $(\mathbf{C O N})$ in which cows were individually offered $6.0 \mathrm{~kg}$ of DM/d of crushed corn grain, $2.0 \mathrm{~kg}$ of $\mathrm{DM} / \mathrm{d}$ of cold-pressed canola meal, $0.2 \mathrm{~kg}$ of $\mathrm{DM} / \mathrm{d}$ of a vitamin and mineral mix (calcium $134 \mathrm{mg} / \mathrm{g}$, magnesium $110 \mathrm{mg} / \mathrm{g}$, phosphorus $60 \mathrm{mg} / \mathrm{g}$, zinc $6.4 \mathrm{mg} / \mathrm{g}$, copper $1.2 \mathrm{mg} / \mathrm{g}$, iodine $80 \mu \mathrm{g} / \mathrm{g}$, cobalt $100 \mu \mathrm{g} / \mathrm{g}$, selenium $24 \mu \mathrm{g} / \mathrm{g}$, vitamin A $51 \mathrm{IU} / \mathrm{g}$, vitamin $\mathrm{D}_{3} 24$ $\mathrm{IU} / \mathrm{g}$, and vitamin E $0.8 \mathrm{IU} / \mathrm{g}$ ), and $14.5 \mathrm{~kg}$ of $\mathrm{DM} / \mathrm{d}$ of alfalfa cubes. The second diet was an almond hull $\operatorname{diet}(\mathbf{A L H})$ in which cows were individually offered 6.0 $\mathrm{kg}$ of DM/d of crushed corn grain, $2.0 \mathrm{~kg}$ of DM/d of cold-pressed canola meal, $0.2 \mathrm{~kg}$ of $\mathrm{DM} / \mathrm{d}$ of minerals, $4.0 \mathrm{~kg}$ of DM/d of almond hulls, and $10.5 \mathrm{~kg}$ of DM/d of alfalfa cubes. The third diet was a citrus pulp diet (CIT) in which cows were individually offered $6.0 \mathrm{~kg}$ of DM/d of crushed corn grain, $2.0 \mathrm{~kg}$ of $\mathrm{DM} / \mathrm{d}$ of cold-pressed canola meal, $0.2 \mathrm{~kg}$ of $\mathrm{DM} / \mathrm{d}$ of minerals, $3.0 \mathrm{~kg}$ of DM/d of ensiled citrus pulp, and $11.5 \mathrm{~kg}$ of $\mathrm{DM} / \mathrm{d}$ of alfalfa cubes. Individual servings of almond hulls were soaked in $1.8 \mathrm{~L}$ of water for $12 \mathrm{~h}$ to increase palatability. The citrus pulp was composed of the skins and pith residue from oranges that had been used to produce orange juice. Given the aim of the investigation was to determine the effect of substituting almond hulls or citrus pulp for alfalfa, we made no attempt to balance for energy or nitrogen.

The CON treatment was randomly assigned to 12 cows, whereas the ALH and CIT treatments were each randomly assigned to 10 cows, subject to the 3 treatment groups being balanced for mean milk yield, BW, and yields of fat and protein according to the method of Baird (1994). Cows were transitioned to their diets on $\mathrm{d} 1$ to 7 , and then all cows were on their assigned diet for the remaining $21 \mathrm{~d}$ of the experiment.

\section{Feeds}

Diets were offered to cows in 2 equal portions, one portion from 0700 to $1100 \mathrm{~h}$ and the other from 1530 to $1930 \mathrm{~h}$ each day. Feeds were offered in a specific sequence. Quantities of corn grain, canola, and minerals offered to individual cows were weighed then mixed by hand in a plastic tub before being offered in the milking parlor during milking. Cows were given up to 30 min to consume their concentrate mix. Refusals 
were collected and weighed, with proportions of each ingredient being assumed to be the same as those offered on a wet weight basis. Cows were then moved to individual stalls within a well-ventilated animal house (Williams et al., 2011). Almond hulls and citrus pulp were offered. Refusals were collected and weighed then alfalfa cubes were offered to all cows. Refusals of alfalfa were collected and weighed at the end of each feeding period. Feeds offered were representatively sampled at each feeding. Dry matter concentration was determined by drying feed samples in a forced-draft oven at $105^{\circ} \mathrm{C}$ for $48 \mathrm{~h}$. Samples of the corn grain, cold-pressed canola meal, almond hulls, ensiled citrus pulp, and alfalfa cubes were kept frozen at $-18^{\circ} \mathrm{C}$, separately bulked over the duration of the experiment, then subsequently freezedried and ground to pass through a $0.5-\mathrm{mm}$ screen. Feeds were analyzed for CP, DM digestibility, NDF, and crude fat by near infrared spectroscopy and ME calculated at the Dairy One Forage Laboratory (Ithaca, NY) using methods detailed in AOAC Official Method 989.03 (AOAC International, 2000). When not in the animal house, cows were either at the dairy parlor being milked (0630-0700 and 1500-1530 h) or held in an outdoor loafing-pad with ad libitum access to water but no access to additional feed.

\section{Milk}

Milk yield of each cow was measured at each milking using a DeLaval Alpro milk metering system (MM25; DeLaval International, Tumba, Sweden). Milk samples were collected from individual cows during morning and afternoon milkings over $4 \mathrm{~d}$ (Monday afternoon to Friday morning) in the week before the experiment (covariate period) and wk 3 and 4 of the experiment. Fat, protein, and lactose in these milk samples were measured by means of a near-infrared milk analyzer (model 2000, Bentley Instruments, Chaska, MN). Somatic cells were counted by a Fossomatic SC300 cell counter (Foss, Hillerød, Denmark). Energy-corrected milk ( $\mathrm{kg} / \mathrm{cow}$ per day), standardized to $4.0 \%$ fat and $3.3 \%$ protein, was calculated using Equation 1 (Tyrrell and Reid, 1965):

$\mathrm{ECM}=\frac{\text { milk yield }(\mathrm{kg}) \times(376 \times \text { fat } \%+209 \times \text { protein } \%+948)}{3,138}$.

Milk fatty acids (MFA) were determined using the method described by Williams et al. (2014b). The mean melting points of milk fat were estimated using the method described by Jensen and Patton (2000) using melting points of individual fatty acids as reported by Weast (1975).

\section{Methane Emissions}

A sulfur hexafluoride $\left(\mathrm{SF}_{6}\right)$ tracer technique (Deighton et al., 2014) was used to estimate methane emissions from individual cows. In this experiment, the permeation tubes (NIWA, Wellington, New Zealand) were filled with about $2.3 \mathrm{~g}$ of $\mathrm{SF}_{6}$. The release rate of $\mathrm{SF}_{6}$ was determined over a 4 -wk period before use by storing the tubes in a dry incubator (Heratherm IMH 60; Thermo Fisher Scientific, Melbourne, Australia) set at $39.0^{\circ} \mathrm{C}$ and weighing each permeation tube twice each week. The release rate of $\mathrm{SF}_{6}$ was $5.8 \pm 0.62 \mathrm{mg} / \mathrm{d}$ (mean $\pm \mathrm{SD}$ ) and ranged from 5.0 to $6.9 \mathrm{mg} / \mathrm{d}$. Each cow was dosed orally with $1 \mathrm{SF}_{6}$ permeation tube on d 15. Permeation tubes were encapsulated in a clear gelatin capsule (Size \#10; Torpac, www.torpac.com) and administered using a balling gun. On d 24 to 28 inclusively, evacuated canisters of $800 \mathrm{~mL}$ were used to continuously sample eructated gases. Orifice plates (5 $\mu \mathrm{m}$ internal diameter; Lenox Laser, Glen Arm, MD) were used to restrict the flow of gases into the collection canisters, and the initial air flow rate was $\sim 0.2 \mathrm{~mL} /$ min. Samples of background gases were also collected into evacuated $800-\mathrm{mL}$ canisters. However, 2 types of background samples were collected each day: 8 samples were collected to represent background gas concentrations when cows were held indoors in the animal house, and 4 other samples representative of background gas concentrations when cows were held outdoors on a loafing pad (Williams et al., 2011). For the background gas samples collected indoors, the chosen initial flow rate was approximately $0.8 \mathrm{~mL} / \mathrm{min}$, because the cows were held indoors for only $8 \mathrm{~h} / \mathrm{d}$. For the background gas samples collected outdoors, the initial flow rate was approximately $0.3 \mathrm{~mL} / \mathrm{min}$ because the cows were outdoors for $16 \mathrm{~h} / \mathrm{d}$. All canisters were exchanged once per day at $\sim 0700 \mathrm{~h}$. The overall background concentrations for individual cows were calculated using the timeweighted average of their indoor and the group outdoor concentrations (Williams et al., 2011). Residual vacuum in all used canisters was recorded before addition of sufficient $\mathrm{N}_{2}(999.99 \mathrm{~g} / \mathrm{kg})$ to bring the remaining vacuum to $\sim 10 \mathrm{kPa}$.

Analysis of collected gas samples was by GC (Williams et al., 2014a). After analysis, the dilution by $\mathrm{N}_{2}$ was accounted for using Equation 2,

$$
\left[G_{\mathrm{S}}\right]=\frac{101-\tau_{\mathrm{f}}}{\tau_{\mathrm{e}}-\tau_{\mathrm{s}}} \times\left[G_{\mathrm{A}}\right]
$$


where $\left[\mathrm{G}_{\mathrm{S}}\right]$ (ppm for $\mathrm{CH}_{4}$, ppt for $\mathrm{SF}_{6}$ ) is the calculated concentration of the gas as sampled, 101 is the average atmospheric pressure $(\mathrm{kPa}), \tau_{\mathrm{f}}(\mathrm{kPa})$ is the final vacuum in the canister after the addition of nitrogen, $\tau_{\mathrm{s}}(\mathrm{kPa})$ is the vacuum in the canister after the sample is collected, $\tau_{\mathrm{e}}(\mathrm{kPa})$ is the vacuum in the evacuated canister before use, and $\left[\mathrm{G}_{\mathrm{A}}\right]$ (same units as $\left[\mathrm{G}_{\mathrm{S}}\right]$ ) is the gas concentration in the sample presented to the GC. Methane emissions for each day were calculated using equation 2 of Williams et al. (2011).

\section{Ruminal Fermentation and Protozoa}

Samples of ruminal fluid $(\sim 400 \mathrm{~mL})$ were collected $\sim 4 \mathrm{~h}$ after the start of feeding from each cow orally on d 28 using a sampling tube and a vacuum pump. The $\mathrm{pH}$ of the ruminal fluid was immediately measured using a Mettler-Toledo FG2 pH meter (Schwerzenbach, Switzerland). A $0.5-\mathrm{mL}$ representative subsample of ruminal fluid was transferred to a $12-\mathrm{mL}$ plastic vial and then diluted with $4.5 \mathrm{~mL}$ of a solution containing $4 \%$ formalin, $0.9 \%$ saline, and $0.4 \%$ methylene blue. These samples were stored in the dark until counted for ciliate protozoa in a Mod-Fuchs-Rosenthal counting chamber (John Morris Scientific, Deepedene, Australia) using a Leica microscope (Leica Microsystems, Macquarie Park, Australia). A 4-mL subsample of ruminal fluid was diluted with $1 \mathrm{~mL}$ of $25 \% \mathrm{H}_{3} \mathrm{PO}_{4}$ then frozen for subsequent analysis of VFA according to the method of Packer et al. (2011).

\section{In Vitro Fermentation of Almond Hulls and Citrus Pulp}

A representative sample $(\sim 1 \mathrm{~kg})$ of alfalfa cubes, almond hulls, and ensiled citrus pulp collected on d 24 to 28 were freeze-dried and ground to pass a $1-\mathrm{mm}$ screen. Analytical DM of feeds was determined by drying the ground samples at $100^{\circ} \mathrm{C}$ for $2 \mathrm{~h}$ (AOAC International, 2000; method 930.05).

Two 24-h, in vitro, batch-culture incubations (runs), as previously described by Meale et al. (2012) and Avila et al. (2011), were conducted using a randomized complete block design with run as block. Briefly, 7 substrates were prepared: alfalfa, alfalfa with almond hulls at 125,250 , and $500 \mathrm{~g} / \mathrm{kg}$ of DM, and alfalfa with citrus pulp at 125,250 , and $500 \mathrm{~g} / \mathrm{kg}$ of DM. On the day before the incubation, $0.5 \mathrm{~g}$ of $\mathrm{DM}$ of each substrate was weighed into an Ankom bag (model F57; Ankom Technology, Macedon, NY) with 2 replicates per treatment and sealed. On the day of incubation, each bag was placed into a $50-\mathrm{mL}$ amber serum bottle with inoculum and sealed with a rubber stopper.
Gas volume and methane concentration were determined after 6,12 , and $24 \mathrm{~h}$ of incubation. Bottles were removed from the incubator for measurement of gas production using the water displacement technique (Fedorak and Hrudey, 1983). Ten milliliters of headspace gas was collected from each bottle and used to fill a 5.9-mL evacuated Exetainer (Labco Ltd., High Wycombe, Buckinghamshire, UK), which was then analyzed for methane concentration by GC (Terry et al., 2016). Both methane and total gas production were expressed as milliliters per gram of DM and per gram of digested DM (DDM) as well as methane expressed as proportion of total gas.

\section{Statistical Analyses}

One cow from each of the ALH and CIT treatments were excluded from the analysis due to ill health. Both cows had been given antibiotics to treat mastitis infections.

For the in vivo experiment, daily feed intake, milk production, milk composition, and methane data were analyzed by a repeated measures ANOVA with factorial treatment structure of diet by day and blocking structure of cow and measurement day within cow. Somatic cell counts were log-transformed before statistical analysis. Dry matter intake and milk production data were analyzed separately for the methane measurement period, as well as for whole of the treatment period. Rumen and fatty acid data were analyzed by ANOVA with diet as treatment structure, and cow as the unit. The ANOVA included treatment contrasts between ALH and CON and between CIT and CON. All pairwise contrasts were computed between treatment means, post-ANOVA subject to significant F-test for differences between means. Distributional assumptions of normality and constant variance were checked visually using histograms, normal quantile plots of residuals, and plots of residuals against fitted values. Analyses were performed using GenStat 17 software (VSN International, Hemel Hempstead, United Kingdom).

For the in vitro experiment, the univariate procedure in SAS was used to test for normal distribution of the data. The data were analyzed using PROC MIXED (SAS Malaysia, Kuala Lumpur, Malaysia) with treatments in the model as fixed effects, run and the run by treatment interaction as random effects, and duplicate within run by treatment as the residual. The run by treatment interaction was used as the error term to test the treatment effect. Differences among means and linear and quadratic orthogonal contrasts for testing trends with proportions of almond hulls or citrus pulp in the feed were tested using the least squares means 
Table 1. Composition of main dietary ingredients

\begin{tabular}{|c|c|c|c|c|c|}
\hline Parameter & Crushed corn & Cold pressed canola & Alfalfa cubes & Almond hulls & Ensiled citrus pulp \\
\hline $\mathrm{CP}$ & 129 & 363 & 214 & 64 & 85 \\
\hline Soluble protein (\% CP) & 19 & 40 & 42 & 22 & 58 \\
\hline $\mathrm{NDF}$ & 101 & 333 & 424 & 508 & 243 \\
\hline $\mathrm{NFC}$ & 717 & 184 & 272 & 330 & 566 \\
\hline TDN & 870 & 765 & 615 & 555 & 690 \\
\hline Sodium & 0.1 & 0.6 & 0.4 & 0.2 & 0.3 \\
\hline Potassium & 3.3 & 13.3 & 33.7 & 30.0 & 12.8 \\
\hline Copper $(\mathrm{mg} / \mathrm{kg}$ of $\mathrm{DM})$ & 4.5 & 7.5 & 8.5 & 12.5 & 7.5 \\
\hline Sulfur & 1.4 & 6.6 & 2.3 & 0.5 & 1.0 \\
\hline Crude fat & 47 & 111 & 18 & 37 & 25 \\
\hline $\mathrm{GE}^{1}(\mathrm{MJ} / \mathrm{kg}$ of $\mathrm{DM})$ & 18.7 & 20.1 & 18.2 & 18.5 & 18.3 \\
\hline $\mathrm{ME}(\mathrm{MJ} / \mathrm{kg}$ of $\mathrm{DM})$ & 16.1 & 16.0 & 11.3 & 10.4 & 12.6 \\
\hline C18:1 cis-9 & 22.5 & 59.1 & 3.4 & 53.3 & 18.6 \\
\hline C18:1 cis-11 & 0.6 & 6.0 & 1.4 & 1.0 & 3.1 \\
\hline C18:2n-6 & 61.4 & 20.1 & 18.1 & 26.2 & 37.8 \\
\hline C18:3 & 1.2 & 6.8 & 28.1 & 2.2 & 8.9 \\
\hline Other & 0.0 & 0.2 & 2.6 & 0.6 & 0.0 \\
\hline
\end{tabular}

${ }^{1} \mathrm{GE}=$ gross energy.

linear hypothesis test, with significance declared when $P \leq 0.05$.

\section{RESULTS}

\section{In Vivo}

Composition of the main dietary ingredients were generally similar (Table 1). Metabolizable energy density in alfalfa cubes was similar to that in both almond hulls and ensiled citrus pulp. Concentration of CP in alfalfa cubes was greater than that in almond hulls and ensiled citrus pulp. Nonfiber carbohydrates in alfalfa cubes were similar to that in almond hulls, but both were about half that in ensiled citrus pulp. Crude fat in alfalfa cubes was about half that in almond hulls, and about three-quarters that in ensiled citrus pulp.

The amount of feed eaten by cows offered the CON $\operatorname{diet}(22.3 \mathrm{~kg}$ of $\mathrm{DM} / \mathrm{d})$ was not different $(P=0.471)$ to that eaten by cows offered the ALH diet $(22.6 \mathrm{~kg}$ of $\mathrm{DM} / \mathrm{d}$ ), but cows in both of these dietary treatment groups ate more than cows offered the CIT diet (21.0 $\mathrm{kg}$ of $\mathrm{DM} / \mathrm{d}, P=0.001$; Table 2). Despite being offered $3.0 \mathrm{~kg}$ of DM/cow per day of ensiled citrus pulp, cows in the CIT group only ate approximately $2.2 \mathrm{~kg}$ of DM/d of this feed. Cows on the CON diet ate more alfalfa $(P$ $<0.001)$ than cows offered ALH or CIT diets, but this was principally because they were offered more alfalfa than cows in the ALH and CIT groups as intended by the treatment design. Whereas cows offered the CON and ALH diets ate more corn and cold-pressed canola than cows offered the CIT $\operatorname{diet}(P=0.001)$, the intakes of these ingredients expressed as proportions of the total dietary intake were not different ( 0.36 of total intake).

Differences in nutrient intake generally reflected the differences in nutrient concentration in the diet ingredients. Cows offered the CON diet ate more $(P<0.001)$ $\mathrm{CP}$ than cows offered the ALH or CIT diets (Table 2), reflecting the low $\mathrm{CP}$ concentration in both almond hulls and citrus pulp compared with alfalfa. The NDF consumption of cows offered the CON diet was less $(P$ $<0.001)$ than that of cows fed ALH, but more $(P<$ 0.001 ) than that of cows offered CIT (Table 2), reflecting the relative concentrations of NDF in the alfalfa, almond hulls, and citrus pulp. Intake of gross energy by cows on each treatment (Table 2) was in proportion to the concentration of gross energy in the main dietary ingredients (alfalfa, almond hulls, and citrus pulp) in each diet. Total milk production and ECM from cows offered the CON diet was greater $(P<0.05)$ than those of cows offered ALH diet, but not different $(P>0.20)$ to those from cows offered the CIT diet (Table 2).

We found no differences in fat, protein, or lactose concentration in the milk of cows fed the 3 dietary treatments $(P>0.10)$. Nor were there any differences 
in SCC $(P>0.20)$ or milk fat yield $(P>0.30)$. However, yields of milk protein and lactose from cows offered the CON diet were greater $(P=0.005)$ than those offered the ALH diet. Yields of milk protein and lactose were not different between cows offered the CON or CIT diets $(P>0.20)$. In general, we noted no differences in the proportion of individual fatty acids in milk; exceptions $(P<0.05)$ were anteiso $\mathrm{C} 15, \mathrm{C} 15: 0$, anteiso $\mathrm{C} 17$, iso C17, C17:0, C18:1 trans-9, C18:1 trans-11, C18:2 n6, and C18:3 n3 (Table 3). The concentration of total PUFA in milk from cows offered the CON diet was greater than in the milk of cows offered the ALH diet $(P=0.040)$, but not different to that in the milk of cows offered the CIT diet $(P=0.189)$. Methane emission $(\mathrm{g} / \mathrm{d})$, methane yield $(\mathrm{g} / \mathrm{kg} \mathrm{DM})$ and methane intensity $(\mathrm{g} / \mathrm{kg}$ of milk; Table 4$)$ were not significantly different between cows offered any of the dietary treatments $(P>0.05)$.

The mean $\mathrm{pH}$ of ruminal fluid from cows offered the CON diet was not different to the $\mathrm{pH}$ in the ruminal fluids of cows offered the ALH $\operatorname{diet}(P=0.457)$, but tended to be greater than the ruminal fluid $\mathrm{pH}$ of cows fed the CIT $\operatorname{diet}(P=0.066)$. However, the $\mathrm{pH}$ in the ruminal fluid of cows offered the ALH diet was greater than the $\mathrm{pH}$ in the ruminal fluid of cows offered the CIT diet $(P<0.05$, Table 5$)$.

The acetate:proprionate ratio $(\mathbf{A}: \mathbf{P})$ in ruminal fluid of cows fed the CON diet was less than for those fed the ALH diet $(P=0.001)$, but was not different to the A:P ratio in cows fed the CIT diet $(P=0.907$, Table 5$)$. The A:P ratio was strongly and positively correlated (Pearson $\mathrm{r}=0.675$ ) with methane yield.

Concentrations of total VFA in the ruminal fluids of the cows fed the 3 dietary treatments were not different $(P>0.25)$, but we observed some minor differences in the proportions of individual VFA (Table 5). Protozoa counts in ruminal fluid were generally not different between dietary treatments. Exceptions were (1) Dasytricha counts in CON cows, which were less than from ALH cows $(P=0.005)$ but not different to cows offered CIT ( $P=0.571$; Table 5$)$; and (2) other protozoa, where counts in CON cows were less than those from ALH cows $(P=0.014)$ but not different to those from cows offered the CIT diet $(P=1.00)$.

Table 2. Feed intake and milk yields from cows on each treatment ${ }^{1}$

\begin{tabular}{|c|c|c|c|c|c|c|}
\hline \multirow[b]{2}{*}{ Parameter } & \multirow[b]{2}{*}{$\mathrm{CON}$} & \multirow[b]{2}{*}{$\mathrm{ALH}$} & \multirow[b]{2}{*}{ CIT } & \multirow[b]{2}{*}{$\mathrm{SED}^{2}$} & \multicolumn{2}{|c|}{ Contrast $P$-value } \\
\hline & & & & & $\mathrm{CON}$ vs. $\mathrm{ALH}$ & CON vs. CIT \\
\hline Number of cows & 12 & 9 & 9 & & - & - \\
\hline \multicolumn{7}{|l|}{ Feed intake $(\mathrm{kg}$ of $\mathrm{DM} / \mathrm{d})$} \\
\hline Alfalfa cubes & $14.2^{\mathrm{c}}$ & $10.5^{\mathrm{a}}$ & $11.0^{\mathrm{b}}$ & 0.175 & $<0.001$ & $<0.001$ \\
\hline Crushed corn grain & $6.0^{\mathrm{b}}$ & $6.0^{\mathrm{b}}$ & $5.8^{\mathrm{a}}$ & 0.066 & 0.688 & 0.001 \\
\hline Cold-pressed canola & $1.9^{\mathrm{b}}$ & $2.0^{\mathrm{b}}$ & $1.8^{\mathrm{a}}$ & 0.029 & 0.694 & 0.001 \\
\hline Minerals & 0.2 & 0.2 & 0.2 & 0.001 & 0.857 & 0.286 \\
\hline Almond hulls & 0 & 3.9 & 0 & & & \\
\hline Ensiled citrus pulp & 0 & 0 & 2.2 & & & \\
\hline Total & $22.3^{\mathrm{b}}$ & $22.6^{\mathrm{b}}$ & $21.0^{\mathrm{a}}$ & 0.301 & 0.471 & 0.001 \\
\hline Total CP & $4.53^{\mathrm{b}}$ & $3.98^{\mathrm{a}}$ & $3.97^{\mathrm{a}}$ & 0.060 & $<0.001$ & $<0.001$ \\
\hline Total NDF & $7.29^{\mathrm{b}}$ & $7.68^{\mathrm{c}}$ & $6.41^{\mathrm{a}}$ & 0.099 & $<0.001$ & $<0.001$ \\
\hline Total fat & $0.76^{\mathrm{b}}$ & $0.83^{\mathrm{c}}$ & $0.73^{\mathrm{a}}$ & 0.021 & $<0.001$ & 0.049 \\
\hline $\mathrm{GEI}^{3}(\mathrm{MJ} / \mathrm{d})$ & $411^{\mathrm{b}}$ & $415^{\mathrm{b}}$ & $386^{\mathrm{a}}$ & 11.6 & 0.007 & 0.002 \\
\hline Concentrate $^{4}(\mathrm{~g} / \mathrm{kg}$ of DM $)$ & $358^{\mathrm{a}}$ & $356^{\mathrm{a}}$ & $363^{\mathrm{b}}$ & 0.900 & 0.105 & $<0.001$ \\
\hline Milk yield $(\mathrm{kg} / \mathrm{d})$ & $27.4^{\mathrm{b}}$ & $24.6^{\mathrm{a}}$ & $26.2^{\mathrm{ab}}$ & 1.04 & 0.013 & 0.278 \\
\hline ECM & $26.4^{\mathrm{b}}$ & $24.6^{\mathrm{a}}$ & $25.4^{\mathrm{ab}}$ & 0.814 & 0.033 & 0.205 \\
\hline Fat & 1.04 & 1.00 & 0.98 & 0.051 & 0.550 & 0.302 \\
\hline Protein & $0.87^{\mathrm{b}}$ & $0.78^{\mathrm{a}}$ & $0.85^{\mathrm{b}}$ & 0.030 & 0.005 & 0.543 \\
\hline Lactose & $1.36^{\mathrm{b}}$ & $1.19^{\mathrm{a}}$ & $1.29^{\mathrm{ab}}$ & 0.053 & 0.005 & 0.249 \\
\hline \multicolumn{7}{|l|}{ Milk composition (\%) } \\
\hline Fat & 3.81 & 4.14 & 3.76 & 0.234 & 0.164 & 0.857 \\
\hline Protein & 3.22 & 3.20 & 3.25 & 0.080 & 0.841 & 0.700 \\
\hline Lactose & 4.99 & 4.88 & 4.93 & 0.066 & 0.115 & 0.389 \\
\hline $\log 10 \mathrm{SCC}$ & 2.19 & 1.89 & 2.07 & 0.232 & 0.211 & 0.611 \\
\hline
\end{tabular}

${ }^{\mathrm{a}-\mathrm{c}}$ Means in the same row followed by different superscripts differ significantly $(P<0.05)$.

${ }^{1} \mathrm{CON}=$ control; $\mathrm{ALH}=$ almond hulls; $\mathrm{CIT}=$ ensiled citrus pulp.

${ }^{2} \mathrm{SED}=$ standard error of the difference.

${ }^{3} \mathrm{GEI}=$ gross energy intake

${ }^{4}$ Concentrate is the sum of crushed corn grain, cold-pressed canola, and minerals as a concentration in the total feed intake. 
WILLIAMS ET AL.

Table 3. Means of fatty acid composition of milk (g/100 g of total fatty acids) and mean melting points of the milk fat from cows offered each dietary treatment ${ }^{1}$

\begin{tabular}{|c|c|c|c|c|c|c|}
\hline \multirow[b]{2}{*}{ Parameter } & \multirow[b]{2}{*}{$\mathrm{CON}$} & \multirow[b]{2}{*}{$\mathrm{ALH}$} & \multirow[b]{2}{*}{ CIT } & \multirow[b]{2}{*}{$\mathrm{SED}^{2}$} & \multicolumn{2}{|c|}{ Contrast $P$-value } \\
\hline & & & & & CON vs. ALH & CON vs. CIT \\
\hline Number of cows & 12 & 9 & 8 & & & \\
\hline $\mathrm{C} 4: 0$ & 1.76 & 1.62 & 1.61 & 0.203 & 0.496 & 0.459 \\
\hline C6:0 & 4.01 & 4.17 & 3.90 & 0.096 & 0.591 & 0.329 \\
\hline $\mathrm{C} 8: 0$ & 2.42 & 2.47 & 2.32 & 0.055 & 0.906 & 0.141 \\
\hline C10:0 & 3.30 & 3.09 & 3.09 & 0.153 & 0.187 & 0.191 \\
\hline C10:1 & 0.32 & 0.33 & 0.32 & 0.018 & 0.727 & 0.917 \\
\hline C12:0 & 3.63 & 3.33 & 3.40 & 0.175 & 0.101 & 0.214 \\
\hline C14:0 & 12.8 & 12.4 & 12.8 & 0.372 & 0.277 & 0.984 \\
\hline anteiso $\mathrm{C} 15$ & $0.19^{\mathrm{b}}$ & $0.16^{\mathrm{a}}$ & $0.15^{\mathrm{a}}$ & 0.010 & 0.049 & 0.009 \\
\hline C14:1 & 1.46 & 1.45 & 1.60 & 0.097 & 0.908 & 0.161 \\
\hline C15:0 & $1.08^{\mathrm{b}}$ & $0.95^{\mathrm{a}}$ & $1.05^{\mathrm{ab}}$ & 0.063 & 0.047 & 0.567 \\
\hline iso $\mathrm{C} 16$ & 0.17 & 0.16 & 0.15 & 0.010 & 0.372 & 0.129 \\
\hline C16:0 & 32.0 & 31.4 & 33.4 & 1.28 & 0.669 & 0.277 \\
\hline anteiso $\mathrm{C} 17$ & $0.29^{\mathrm{b}}$ & $0.23^{\mathrm{a}}$ & $0.26^{\mathrm{ab}}$ & 0.019 & 0.007 & 0.210 \\
\hline C16:1 & 1.40 & 1.27 & 1.35 & 0.128 & 0.304 & 0.676 \\
\hline iso $\mathrm{C} 17$ & $0.37^{\mathrm{b}}$ & $0.29^{\mathrm{a}}$ & $0.35^{\mathrm{b}}$ & 0.021 & 0.001 & 0.258 \\
\hline C17:0 & $0.60^{\mathrm{b}}$ & $0.54^{\mathrm{a}}$ & $0.60^{\mathrm{b}}$ & 0.020 & 0.011 & 0.937 \\
\hline C17:1 & 0.23 & 0.21 & 0.24 & 0.016 & 0.298 & 0.345 \\
\hline C18:0 & 7.27 & 8.33 & 7.28 & 0.573 & 0.077 & 0.990 \\
\hline C18:1 trans-9 & $0.34^{\mathrm{a}}$ & $0.43^{\mathrm{b}}$ & $0.31^{\mathrm{a}}$ & 0.034 & 0.012 & 0.404 \\
\hline C18:1 trans-10 & 0.43 & 0.47 & 0.41 & 0.034 & 0.254 & 0.671 \\
\hline C18:1 trans-11 & $0.92^{\mathrm{ab}}$ & $1.02^{\mathrm{b}}$ & $0.77^{\mathrm{a}}$ & 0.110 & 0.358 & 0.194 \\
\hline C18:1 cis-9 & 20.4 & 21.5 & 20.3 & 0.91 & 0.238 & 0.949 \\
\hline $\mathrm{C} 18: 1$ cis-11 & 0.47 & 0.44 & 0.47 & 0.030 & 0.448 & 0.945 \\
\hline C18:2n-6 & $1.64^{\mathrm{b}}$ & $1.38^{\mathrm{a}}$ & $1.55^{\mathrm{ab}}$ & 0.117 & 0.034 & 0.449 \\
\hline C20:0 & 0.11 & 0.12 & 0.11 & 0.005 & 0.263 & 0.373 \\
\hline C18:3n-3 & $0.56^{\mathrm{b}}$ & $0.40^{\mathrm{a}}$ & $0.50^{\mathrm{b}}$ & 0.043 & 0.001 & 0.142 \\
\hline CLA & 0.54 & 0.54 & 0.42 & 0.055 & 0.978 & 0.051 \\
\hline Total MUFA & 25.9 & 27.0 & 25.8 & 1.05 & 0.284 & 0.889 \\
\hline Total PUFA & $2.74^{\mathrm{b}}$ & $2.31^{\mathrm{a}}$ & $2.47^{\mathrm{ab}}$ & 0.198 & 0.040 & 0.189 \\
\hline Total de novo & 46.6 & 45.5 & 46.7 & 0.93 & 0.226 & 0.949 \\
\hline Melting point $\left({ }^{\circ} \mathrm{C}\right)$ & 38.0 & 37.6 & 38.6 & 0.58 & 0.230 & 0.361 \\
\hline
\end{tabular}

$\overline{\mathrm{a}, \mathrm{b}}$ Means in the same row followed by different superscripts differ significantly $(P<0.05)$.

${ }^{1} \mathrm{CON}=$ control; $\mathrm{ALH}=$ almond hulls; $\mathrm{CIT}=$ ensiled citrus pulp.

${ }^{2} \mathrm{SED}=$ standard error of the difference.

\section{In Vitro}

Substituting almond hulls or ensiled citrus pulp in place of alfalfa in the substrate did not alter total gas production $(P>0.3$; Table 6$)$. However, we noted a linear trend of reducing methane $(\mathrm{mL} / \mathrm{g}$ of DDM $P$ $=0.030$, and $\%$ total gas $P=0.014)$ with increasing proportions of almond hulls replacing alfalfa as sub-

Table 4. Influence of diet on methane emissions and milk and DMI during the period of methane measurement ${ }^{1}$

\begin{tabular}{|c|c|c|c|c|c|c|}
\hline \multirow[b]{2}{*}{ Parameter } & \multirow[b]{2}{*}{$\mathrm{CON}$} & \multirow[b]{2}{*}{$\mathrm{ALH}$} & \multirow[b]{2}{*}{ CIT } & \multirow[b]{2}{*}{$\mathrm{SED}^{2}$} & \multicolumn{2}{|c|}{ Contrast $P$-value } \\
\hline & & & & & CON vs. ALH & CON vs. CIT \\
\hline Number of cows & 12 & 9 & 9 & & & \\
\hline $\mathrm{CH}_{4}(\mathrm{~g} / \mathrm{cow}$ per day $)$ & 400 & 430 & 414 & 30.1 & 0.325 & 0.635 \\
\hline $\mathrm{CH}_{4}(\mathrm{~g} / \mathrm{kg}$ of $\mathrm{DMI})$ & 17.8 & 19.1 & 19.0 & 1.26 & 0.330 & 0.338 \\
\hline $\mathrm{CH}_{4}(\mathrm{~g} / \mathrm{kg}$ of milk) & 14.8 & 17.7 & 16.6 & 1.73 & 0.104 & 0.304 \\
\hline $\mathrm{CH}_{4}\left(\% \mathrm{GEI}^{3}\right)$ & 5.4 & 5.8 & 6.0 & 0.45 & 0.091 & 0.179 \\
\hline Milk $(\mathrm{kg} / \mathrm{d})$ & $27.2^{\mathrm{b}}$ & $24.5^{\mathrm{a}}$ & $26.1^{\mathrm{ab}}$ & 1.10 & 0.022 & 0.332 \\
\hline DMI (kg/cow per day) & $22.4^{\mathrm{b}}$ & $22.6^{\mathrm{b}}$ & $21.6^{\mathrm{a}}$ & 0.21 & 0.594 & $<0.001$ \\
\hline
\end{tabular}

${ }^{\mathrm{a}, \mathrm{b}}$ Means in the same row followed by different superscripts differ significantly $(P<0.05)$.

${ }^{1} \mathrm{CON}=$ control, $\mathrm{ALH}=$ almond hulls, $\mathrm{CIT}=$ ensiled citrus pulp.

${ }^{2} \mathrm{SED}=$ standard error of the difference.

${ }^{3} \mathrm{GEI}=$ gross energy intake. 
Table 5. Influence of diet on rumen fluid $\mathrm{pH}$, concentrations of rumen fluid constituents, and rumen protozoa ${ }^{1}$

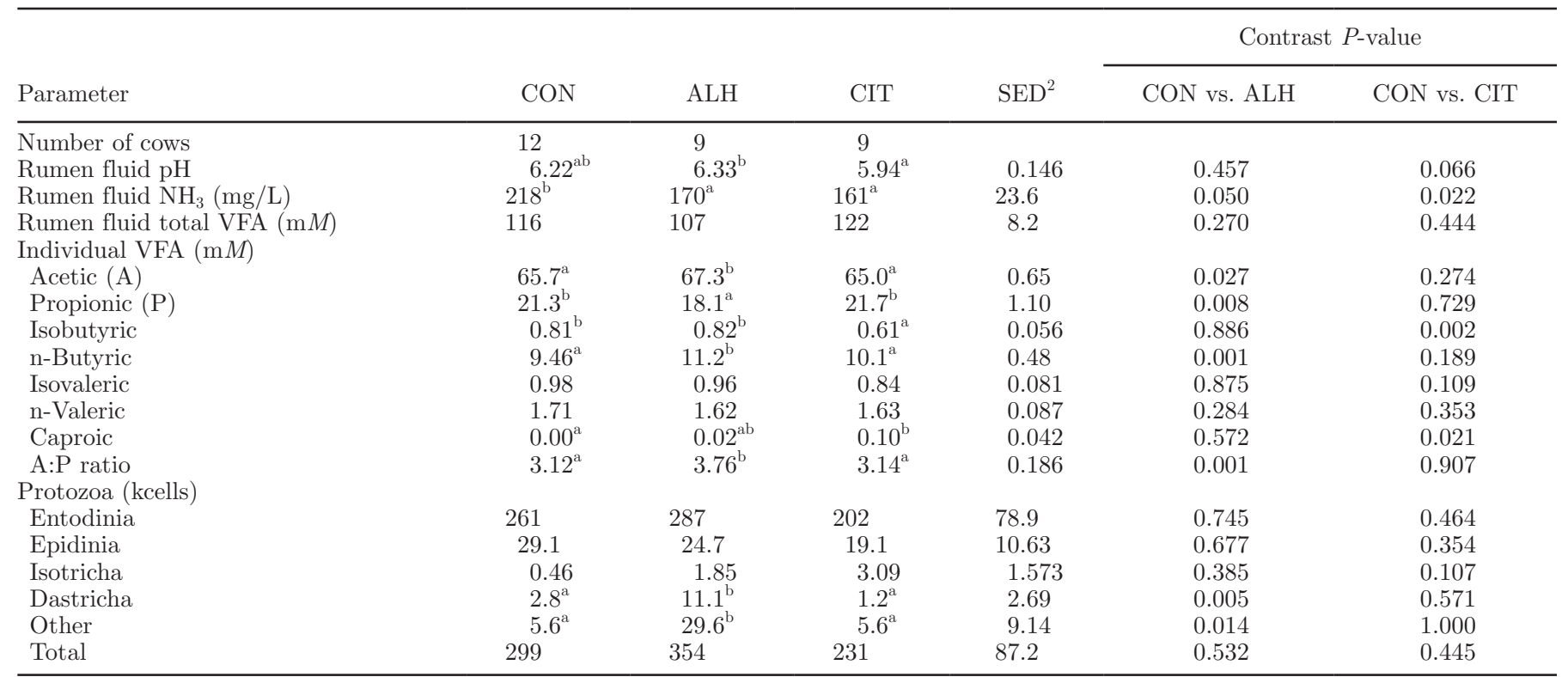

${ }^{\mathrm{a}, \mathrm{b}}$ Means in the same row followed by different superscripts differ significantly $(P<0.05)$.

${ }^{1} \mathrm{CON}=$ control, $\mathrm{ALH}=$ almond hulls, $\mathrm{CIT}=$ ensiled citrus pulp.

${ }^{2} \mathrm{SED}=$ standard error of the differene.

strate. Substituting alfalfa with ensiled citrus pulp had no effect on $\mathrm{CH}_{4}$ production (mL/g of DDM, $P>0.4$ ) or concentration (\% total gas, $P>0.9$ ).

\section{DISCUSSION}

Substituting almond hulls into the diet of dairy cows in place of alfalfa cubes reduced milk production and the yields of milk protein and milk lactose, but the concentrations of fat, protein, and lactose in milk were unaffected; this was despite DMI being the same for the 2 diets. In contrast, other researchers found dairy cows offered diets containing 1, 12.5, or $25 \%$ almond hulls produced similar milk yields (Aguilar et al., 1984). However, in the study by Aguilar et al. (1984), the diets containing almond hulls were fortified with urea such that each diet was reported to have a similar concentration of CP. Similarly, when lactating goats were fed

Table 6. Influence of almond hulls and citrus pulp on production of methane and total gas in vitro

\begin{tabular}{lccc}
\hline Treatment & $\begin{array}{c}\text { Total gas } \\
\left(\mathrm{mL} / \mathrm{g} \text { of } \mathrm{DDM}^{1}\right)\end{array}$ & $\begin{array}{c}\text { Methane } \\
(\mathrm{mL} / \mathrm{g} \text { of DDM })\end{array}$ & $\begin{array}{c}\text { Methane } \\
(\% \text { total gas })\end{array}$ \\
\hline Almond hulls & & & \\
$0.0 \%$ & 189 & $29.6^{\mathrm{b}}$ & $15.6^{\mathrm{b}}$ \\
$12.5 \%$ & 180 & $28.0^{\mathrm{ab}}$ & $15.6^{\mathrm{b}}$ \\
$25.0 \%$ & 181 & $27.5^{\mathrm{ab}}$ & $15.2^{\mathrm{ab}}$ \\
$50.0 \%$ & 181 & $25.5^{\mathrm{a}}$ & $14.0^{\mathrm{a}}$ \\
SED $^{2}$ (treat with control) & 7.1 & 1.43 & 0.51 \\
$P$-value & & & 0.014 \\
Linear & 0.412 & 0.030 & 0.372 \\
Quadratic & 0.331 & & 15.6 \\
Citrus pulp & 189 & 29.6 & 15.9 \\
$0.0 \%$ & 189 & 30.1 & 15.6 \\
$12.5 \%$ & 194 & 28.4 & 0.5 \\
$25.0 \%$ & 191 & 30.1 & 0.51 \\
$50.0 \%$ & 7.1 & & 1.43 \\
SED (treat with control) & & 0.851 & 0.991 \\
$P$-value & 0.862 & 0.463 & 0.902 \\
Linear & 0.300 & & \\
Quadratic & & & \\
\hline
\end{tabular}

$\overline{\mathrm{a}, \mathrm{b}}$ Within a feed type, means in the same column with different superscripts differ significantly $(P<0.05)$.

${ }^{1} \mathrm{DDM}=$ digestible $\mathrm{DM}$.

${ }^{2} \mathrm{SED}=$ standard error of the difference. 
dietary supplements containing almond hulls and urea, milk production was not decreased but the concentration of protein in milk increased with increasing $\mathrm{CP}$ concentration in the diet (Reed and Brown, 1988). In our experiment the concentration of $\mathrm{CP}$ in the $\mathrm{CON}$ diet $(202 \mathrm{~g} / \mathrm{kg}$ of $\mathrm{DM})$ was greater than that in the ALH diet (176 g/ $\mathrm{kg}$ of DM) because the almond hulls (64 $\mathrm{g}$ of $\mathrm{CP} / \mathrm{kg}$ of $\mathrm{DM})$ partially replaced the higherprotein alfalfa ( $214 \mathrm{~g}$ of $\mathrm{CP} / \mathrm{kg}$ of $\mathrm{DM})$. The chemical characteristics of the almond hulls in our experiment were generally in the range of published values (e.g., Alibés et al., 1983; Yalchi 2011). This suggests that protein supplementation may be necessary to maintain milk yield when almond hulls replace a higher-protein feed.

Substituting ensiled citrus pulp into the diet of dairy cows in place of alfalfa cubes had no effect on milk yield, the concentrations of major milk components, or the yield of milk components. In previous research, the production response of animals fed citrus pulp depended on the form of citrus pulp and what the citrus pulp replaced in the diet. For example, dairy cows have been reported to produce less milk and have lower milk protein concentration and greater milk fat concentration when dried citrus pulp replaced $17 \%$ of a diet dominant in corn grain (Hall et al., 2010). However, when citrus pulp replaced $26 \%$ of a diet dominant in ground corn, cows produced similar yields of milk and milk fat, but had a lower milk protein concentration than those cows offered corn only (Gehman et al., 2006). In another experiment, Leiva et al. (2000) reported that when dried citrus pulp replaced corn, cows offered the diet with citrus pulp had lower milk yield, lower ECM, and lower milk protein but higher milk fat concentration than those cows offered the corn diet. Wickes and Bartsch, (1978) also investigated the effects of feeding citrus pulp to dairy cows and reported that when dried citrus pulp (0 to $3.4 \mathrm{~kg} / \mathrm{d}$ ) replaced barley in the diet of dairy cows, milk protein concentration decreased and the milk had a citrus taint. In contrast to these results, van Horn et al. (1975) reported that replacing corn in the diet of dairy cows with citrus pulp (type unspecified) resulted in an increase in the milk fat concentration. Increases in dairy cow production were also reported when dried citrus pulp was added to the diet at $20 \%$ in place of dried beet pulp (Belibasakis and Tsirgogianni, 1996). The protein concentration of citrus pulp used in our experiment was in the range of published values (e.g., Grasser et al., 1995; Sunvold et al., 1995; DePeters et al., 1997); however, the calculated ME of our citrus pulp was greater than values found in the literature (e.g., Grasser et al., 1995; DePeters et al., 1997). Palatability of citrus pulp appears to have been lower in our experiment than in published reports. We were only able to get cows to eat $10.5 \%$ of their diet as citrus pulp, which is lower than reported by other researchers. The composition of our citrus pulp may be responsible for these differences. Our citrus pulp had a high proportion of skins, and hence pith, and was wet $(15 \% \mathrm{DM})$. Other researchers have reported on drier citrus pulp (e.g., 90\% DM, Arosemena et al., 1995; 30\% DM, Grasser et al., 1995; 91\% DM, Sunvold et al., 1995), whereas the proportion of skins and citrus variety have not been reported. Our citrus pulp was also ensiled; we speculate that differences in the physical and chemical composition of citrus pulp such as these may explain the variety of performance responses reported when citrus pulp is fed to dairy cows.

In times of drought, farmers have been advised to consider alternative forage sources and high-fiber byproducts (e.g., Jordan et al., 2017), but with a focus on the economics of the nutrition being provided (DAF, 2017). In our experiment, we found no reduction in ECM when citrus pulp was fed and only a $10 \%$ reduction in ECM when almond hulls were fed. In addition, previous research has shown that fortifying almond hulls with urea results in no reduction in milk production (Aguilar et al., 1984). This suggests that although almond hulls and citrus pulp are not replacements for high-quality forages, they are nutritionally viable alternatives for the feeding of dairy cows when traditional feeds, such as pasture or alfalfa hay, are scarce or expensive.

Methane emission, yield, and intensity were unaffected by replacing alfalfa with almond hulls or citrus pulp in the diets of dairy cows. This was contrary to our second hypothesis. Methane emission is generally driven by intake (Charmley et al., 2016); however, the common association between methane emission and intake does not hold in all situations. For example, less methane is emitted when dairy cows are fed diets with a high concentration of fat (e.g., Moate et al., 2011). For this reason, we focused our discussion on methane yield, which better reflects if a reduction in methane is a true reduction rather than simply a reduction in feed intake. Almond hulls contain phenolics (Esfahlan et al., 2010), and feeds containing phenolics have been shown in vitro to reduce methane when combined with feeds with high digestibility (Jayanegara et al., 2013). Almond hulls also contain triterpenoids (Takeoka et al., 2000), which have been shown to reduce methane production when added to an anaerobic incubation sludge from a biogas production plant (Wikandari et al., 2013). When almond hulls were incubated in vitro with an equal quantity of control substrate (barley, oats, wheat, straw, and lupins as a mixed pellet), methane production was a lesser proportion of total gas than when the control substrate was incubated alone (Durmic et al., 2014). These associations and results 
suggest that almond hulls should have reduced methane yield, but this was not the case in our experiment. Our measured methane yield of cows fed ALH (19.1 g/ $\mathrm{kg}$ of DM) was less than the $21.4 \mathrm{~g} / \mathrm{kg}$ of DM reported by Moate et al. (2016) for 220 observations of dairy cows in respiration chambers, but our value fits within their spread of data. No reports of methane emissions from ruminants fed almond hulls could be found in the scientific literature. Whereas our in vitro results suggested a trend of reducing methane with increasing proportion of almond hulls, we found no difference at the inclusion rate used in the ALH diet $(173 \mathrm{~g} / \mathrm{kg})$. Citrus pulp has been reported to contain limonene (Kamalak et al., 2011), polyphenols, and flavonoids (Lima et al., 2014). Limonene has been shown to have antimethanogenic properties (Kamalak et al., 2011), as have polyphenols (Jayanegara et al., 2013) and flavonoids (Wikandari et al., 2013). Dairy goats fed citrus pulp at $60 \%$ of their diet in place of corn grain had greater methane yield $(23.0 \mathrm{~g} / \mathrm{kg}$ of DM) than those fed corn grain $(16.4 \mathrm{~g} / \mathrm{kg}$ of $\mathrm{DM})$, with this difference thought to be influenced by the type of carbohydrates in each diet (López et al., 2014). The findings of López et al. (2014) may perhaps be explained by the fact that citrus pulp contains a substantial amount of pectins, whereas corn grain contains starch, which is less methanogenic than pectin (Hindrichsen et al., 2004). The difference in methane yield reported by López et al. (2014) may also be explained by the proportion of grain in the diet. As the proportion of grain in the diet increases above $300 \mathrm{~g} / \mathrm{kg}$ of DM, the methane yield decreases (Sauvant et al., 2011). In our experiment, citrus pulp replaced alfalfa cubes, the proportion of grain in each diet was not different, and methane yields were not different. In our experiment, the methane yield of cows fed the CIT diet $(19.0 \mathrm{~g} / \mathrm{kg}$ of DM) was less than the $21.4 \mathrm{~g} /$ $\mathrm{kg}$ of DM reported by Moate et al. (2016) but is within the range of their data. Our in vitro results showed no change in methane as a proportion of total gas, even at an inclusion rates more than 4 times that used in vivo, supporting our in vivo results.

The concentrations of individual fatty acids in the milk fat of cows fed almond hulls or citrus pulp were generally not different to those in the milk of the cows fed the control diet. The estimated melting points of the milk fats were also unaffected by dietary supplementation with either almond hulls or citrus pulp. Thus, our third hypothesis was rejected. Concentrations of most fatty acids in milk were within previously reported ranges (Moate et al., 2007). Therefore, it is unlikely that the supplementary feeding of almond hulls or citrus pulp to dairy cows would cause any significant negative effect on the suitability of resulting milk for manufacture of dairy products.
Volatile fatty acids in ruminal fluid were affected by diet. In general, the VFA profile of cows fed CON was different to those fed ALH but not those fed CIT. The $\mathrm{A}: \mathrm{P}$ ratio in the ruminal fluid of cows fed the CON diet was smaller than that in the ruminal fluid of cows fed the ALH diet, but not different to that in the ruminal fluid of cows fed the CIT diet. This is surprising given the A:P ratio has been shown to be positively correlated with methane yield (g/kg of DM; e.g., Mohammed et al., 2004; Holtshausen et al., 2009; Eugène et al., 2011), but in our experiment methane yield was not different between the 3 diets. Adding citrus pulp to the diet of beef steers (Hentges et al., 1966) and dairy cattle (Drude et al., 1971; Wing 1975) increased the $\mathrm{A}: \mathrm{P}$ ratio; however, it has also been reported that when citrus pulp was fed to dairy cows there was no change in A:P ratio (Hall et al., 2010). In those previous experiments, citrus pulp was substituted for corn grain and the results may not necessarily reflect the effect of citrus pulp per se, but reflect the fact that the A:P ratio is negatively related to the proportion of concentrate in the diet (Sauvant et al., 2011). The A:P ratio has been reported to relate to methane yield (e.g.: Sauvant et al., 2011), but this is clearly not so in our current experiment.

The minimum number of animals per treatment in experiments using $\mathrm{SF}_{6}$ has been proposed as 10 (Berndt et al., 2014). As designed, our trial did have 2 treatments with 10 cows each, as well as a control with 12 cows. However, 1 cow dropped out of each of the 2 noncontrol treatment groups due to unrelated health issues. Thus, we were theoretically 1 cow short in 2 treatments groups; however, we note that the recommendation of Berndt et al. (2014) is based on historical coefficient of variation of 11 to $16 \%$. Our implementation of the SF6 technique is that of Deighton et al. (2014), where orifice plates are used to restrict the flow of gas into the collection vessels. This modification has enabled us to achieve a coefficient of variation of as little as $6.5 \%$ (Deighton et al., 2014), meaning less animals are required to achieve the same power. Furthermore, the effect on power of 9 relative to 10 cows per group is rather small. In fact, the standard error of the difference between a group of 9 and the control group of 12 cows in this trial is actually slightly smaller (by 1.4\%) than it would be between 2 groups of 10 cows. However, the real question is whether the number of animals was sufficient for the purposes of the current trial. With methane yield we see that the standard error of the difference was 1.26 ; this means that a treatment effect of approximately twice this (i.e., LSD $=2.52$, or about $15 \%$ of the control) would be needed to achieve statistical significance in this trial. The maximal observed difference was 1.2 , about $7 \%$ of the control. For 
an effect of $7 \%$ to be just significant, we would need to have 4.4 times as many cows (i.e., $2.52 / \sqrt{ } 4.4=1.2$ ). For gross energy intake, the maximal observed effect was 0.6 (11\% of the control) and the least significant difference was 0.90 (17\% of the control). For an effect of $11 \%$ to be significant, we would need 2.25 times as many cows. The change in least significant difference (e.g., from LSD $=2.52$ to 2.39 ) produced by having 10 cows (the minimum recommended) rather than 9 cows per treatment group is quite small, and would not have materially altered the results of our study. For both of these variables, the current trial was easily capable of detecting a $20 \%$ effect due to diet had such been present.

\section{CONCLUSIONS}

Substituting almond hulls into the diet of dairy cows in place of alfalfa cubes reduced milk production and the yield of milk protein, whereas replacing alfalfa cubes with ensiled citrus pulp had no effect on milk yield, the concentration of milk components, or the yield of milk components. Methane emission, yield, and intensity were unaffected by replacing alfalfa with almond hulls or ensiled citrus pulp in the diets of dairy cows, even though VFA in ruminal fluid were affected by diet. These findings indicate that, although almond hulls and ensiled citrus pulp can be used as a low-cost feed supplement, almond hulls negatively affected milk production and neither inhibited enteric methane emissions.

\section{ACKNOWLEDGMENTS}

This investigation was funded by the Victorian Department of Economic Development, Jobs, Transport and Resources (Melbourne, Australia); Meat and Livestock Australia (North Sydney, Australia); and the Australian Government Department of Agriculture (Canberra). This work would not have been possible without the excellent work of the technical staff at the Victorian Department of Economic Development, Jobs, Transport and Resources, Ellinbank Centre (Ellinbank, Australia).

\section{REFERENCES}

Aguilar, A. A., N. E. Smith, and R. L. Baldwin. 1984. Nutritional value of almond hulls for dairy cows. J. Dairy Sci. 67:97-103.

Alibés, X., M. R. Maestre, F. Muñoz, J. Combellas, and J. Rodriguez. 1983. Nutritive value of almond hulls for sheep. Anim. Feed Sci. Technol. 8:63-67.

AOAC International. 2000. Official Methods of Analysis of AOAC International. 17th ed. AOAC International, Gaithersburg, MD.
Arosemena, A., E. J. DePeters, and J. G. Fadel. 1995. Extent of variability in nutrient composition within selected by-product feedstuffs. Anim. Feed Sci. Technol. 54:103-120.

Avila, J. S., A. V. Chaves, M. Hernandez-Calva, K. A. Beauchemin, S. M. McGinn, Y. Wang, O. M. Harstad, and T. A. McAllister. 2011. Effects of replacing barley grain in feedlot diets with increasing levels of glycerol on in vitro fermentation and methane production. Anim. Feed Sci. Technol. 166-167:265-268.

Baird, D. B. 1994. The design of experiments with covariates. PhD Thesis, University of Otago, New Zealand.

Belibasakis, N. G., and D. Tsirgogianni. 1996. Effects of dried citrus pulp on milk yield, milk composition and blood components of dairy cows. Anim. Feed Sci. Technol. 60:87-92.

Berndt, A., T. M. Boland, M. H. Deighton, J. I. Gere, C. Grainger, R. S. Hegarty, A. D. Iwaasa, J. P. Koolaard, K. R. Lassey, D. Luo, R. J. Martin, C. Martin, P. J. Moate, G. Molano, C. Pinares-Patiño, B. E. Ribaux, N. M. Swainson, G. C. Waghorn, and S. R. O Williams. 2014. Guidelines for Use of Sulphur Hexafluoride $\left(\mathrm{SF}_{6}\right)$ Tracer Technique to Measure Enteric Methane Emissions from Ruminants. New Zealand Agricultural Greenhouse Gas Research Centre, Palmerston North, New Zealand.

Can, A., N. Denek, and M. Seker. 2007. Effect of replacing wheat straw with almond hull and shell in diets on nutrient digestibility and blood parameters of goat. J. Appl. Anim. Res. 32:181-183.

Charmley, E., S. R. O. Williams, P. J. Moate, R. S. Hegarty, R. M Herd, V. H. Oddy, P. Reyenga, K. M. Staunton, A. Anderson, and M. C. Hannah. 2016. A universal equation to predict methane production of forage-fed cattle in Australia. Anim. Prod. Sci. 56:169-180. https://doi.org/10.1071/AN15365.

DAF. 2017 Drought management strategies for dairy farmers. Accessed Oct. 20, 2017. https://www.daf.qld.gov.au/environment/drought/ managing-drought/drought-strategies/drought-management -strategies-for-dairy-farmers.

Deighton, M. H., S. R. O. Williams, M. C. Hannah, R. J. Eckard, T. M. Boland, W. J. Wales, and P. J. Moate. 2014. A modified sulphur hexafluoride tracer technique enables accurate determination of enteric methane emissions from ruminants. Anim. Feed Sci. Technol. 197:47-63.

DePeters, E. J., J. G. Fadel, and A. Arosemena. 1997. Digestion kinetics of neutral detergent fiber and chemical composition within some selected by-product feedstuffs. Anim. Feed Sci. Technol. $67: 127-140$.

Dijkstra, J., S. M. van Zijderveld, J. A. Apajalahti, A. Bannink, W J. J. Gerrits, J. R. Newbold, H. B. Perdok, and H. Berends. 2011. Relationships between methane production and milk fatty acid profiles in dairy cattle. Anim. Feed Sci. Technol. 166-167:590-595.

Drude, R. E., J. R. Escano, and L. L. Rusoff. 1971. Value of complete feeds containing combinations of corn silage, alfalfa pellets, citrus pulp, and cottonseed hulls for lactating cows. J. Dairy Sci. 54:773.

Durmic, Z., P. J. Moate, R. Eckard, D. K. Revell, R. Williams, and P. E. Vercoe. 2014. In vitro screening of selected feed additives, plant essential oils and plant extracts for rumen methane mitigation. J. Sci. Food Agric. 94:1191-1196.

Esfahlan, A. J., R. Jamei, and R. J. Esfahlan. 2010. The importance of almond (Prunus amygdalus L.) and its by-products. Food Chem. 120:349-360.

Eugène, M., C. Martin, M. M. Mialon, D. Krauss, G. Renand, and M. Doreau. 2011. Dietary linseed and starch supplementation decreases methane production of fattening bulls. Anim. Feed Sci. Technol. 166-167:330-337.

Fedorak, P. M., and S. E. Hrudey. 1983. A simple apparatus for measuring gas-production by methanogenic cultures in serum bottles. Environ. Technol. Lett. 4:425-432.

Gehman, A. M., J. A. Bertrand, T. C. Jenkins, and B. W. Pinkerton. 2006. The effect of carbohydrate source on nitrogen capture in dairy cows on pasture. J. Dairy Sci. 89:2659-2667.

Grasser, L. A., J. G. Fadel, I. Garnett, and E. J. Depeters. 1995. Quantity and economic importance of nine selected by-products used in California dairy rations. J. Dairy Sci. 78:962-971. 
Hall, M. B., C. C. Larson, and C. J. Wilcox. 2010. Carbohydrate source and protein degradability alter lactation, ruminal, and blood measures. J. Dairy Sci. 93:311-322.

Hentges, J. F., J. E. Moore, A. Z. Palmer, and J. W. Carpenter. 1966. Replacement value of dried citrus meal for corn meal in beef cattle diets. Bulletin 708 (Technical). Institute of Food and Agricultural Sciences, University of Florida, Gainesville. Accessed Apr. 22, 2016. http://ufdc.ufl.edu/UF00027132/00001/1j.

Hillbrick, G., and M. A. Augustin. 2002. Milkfat characteristics and functionality: Opportunities for improvement. Aust. J. Dairy Technol. 57:45-51.

Hindrichsen, I. K., H. R. Wettstein, A. Machmüller, C. R. Soliva, K. E. Bach Knudsen, J. Madsen, and M. Kreuzer. 2004. Effects of feed carbohydrates with contrasting properties on rumen fermentation and methane release in vitro. Can. J. Anim. Sci. 84:265-276.

Holtshausen, L., A. V. Chaves, K. A. Beauchemin, S. M. McGinn, T. McAllister, and N. Odongo. 2009. Feeding saponin-containing Yucca schidigera and Quillaja saponaria to decrease enteric methane production in dairy cows. J. Dairy Sci. 92:2809-2821.

Jaramillo, D. P., T. García, M. Buffa, M. Rodríguez, B. Guamis, and A. Trujillo. 2009. Effect of the inclusion of whole citrus in ration of lactating ewes on the properties of milk and cheese characteristics during ripening. J. Dairy Sci. 92:469-476.

Jayanegara, A., S. Marquardt, E. Wina, M. Kreuzer, and F. Leiber. 2013. In vitro indications for favourable non-additive effects on ruminal methane mitigation between high-phenolic and high-quality forages. Br. J. Nutr. 109:615-622.

Jensen, R. G., and S. Patton. 2000. The effect of maternal diets on the mean melting points of human milk fatty acids. Lipids 35:11591161.

Jordan, E., K. Lager, R. Bruno, and T. Bilby. 2017. Systematic drought feeding strategies. Accessed Oct. 20, 2017. http://agrilife .org/texasdairymatters/files/2010/07/10-11-Jordan_Systematic -Drought-Feeding-Strategies-Updated-01-17-1.pdf.

Kamalak, A., A. I. Atalay, C. O. Ozkan, A. Tatliyer, and E. Kaya. 2011. Effect of essential orange (Citrus sinensis L.) oil on rumen microbial fermentation using in vitro gas production technique. J. Anim. Plant Sci. 21:764-769.

Leiva, E., M. B. Hall, and H. H. van Horn. 2000. Performance of dairy cattle fed citrus pulp or corn products as sources of neutral detergent-soluble carbohydrates. J. Dairy Sci. 83:2866-2875.

Lima, L. S., G. T. Santos, A. B. Schogor, J. C. Damasceno, F. E. Marchi, N. W. Santos, F. S. Santos, and H. V. Petit. 2014. Effect of abomasal or ruminal supplementation of citrus pulp and soybean oil on nutrient digestibility and ruminal fermentation of dairy cows. Anim. Feed Sci. Technol. 189:123-129.

López, M. C., F. Estellés, V. J. Moya, and C. Fernández. 2014. Use of dry citrus pulp or soybean hulls as a replacement for corn grain in energy and nitrogen partitioning, methane emissions, and milk performance in lactating Murciano-Granadina goats. J. Dairy Sci. 97:7821-7832.

Meale, S. J., A. V. Chaves, J. Baah, and T. A. McAllister. 2012. Methane production of different forages in in vitro ruminal fermentation. Asian-Australas. J. Anim. Sci. 25:86-91.

Moate, P. J., W. Chalupa, R. C. Boston, and I. J. Lean. 2007. Milk fatty acids I. Variation in concentration of individual fatty acids in bovine milk. J. Dairy Sci. 90:4730-4739.

Moate, P. J., M. H. Deighton, S. R. O. Williams, J. E. Pryce, B. J. Hayes, J. L. Jacobs, R. J. Eckard, M. C. Hannah, and W. J. Wales. 2016. Reducing the carbon footprint of Australian milk production by mitigation of enteric methane emissions. Anim. Prod. Sci. 56:1017-1034. https://doi.org/10.1071/AN15222.

Moate, P. J., S. R. O. Williams, C. Grainger, M. C. Hannah, E. N. Ponnampalam, and R. J. Eckard. 2011. Influence of cold-pressed canola, brewers grains and hominy meal as dietary supplements suitable for reducing enteric methane emissions from lactating dairy cows. Anim. Feed Sci. Technol. 166-167:254-264.

Mohammed, N., N. Ajisaka, Z. A. Lila, K. Hara, K. Mikuni, S. Kanda, and H. Itabashi. 2004. Effect of Japanese horseradish oil on meth- ane production and ruminal fermentation in vitro and in steers. J. Anim. Sci. 82:1839-1846.

NHMRC. 2004. Australian Code of Practice for the Care and Use of Animals for Scientific Purposes. 7th ed. National Health and Medical Research Council, Canberra, Australia.

Packer, E. L., E. H. Clayton, and P. M. V. Cusack. 2011. Rumen fermentation and liveweight gain in beef cattle treated with monensin and grazing lush forage. Aust. Vet. J. 89:338-345.

Reed, B. A., and D. L. Brown. 1988. Almond hulls in diets for lactating goats: effects on yield and composition of milk, feed intake, and digestibility. J. Dairy Sci. 71:530-533.

Sauvant, D., S. Giger-Reverdin, A. Serment, and L. Broudiscou. 2011. Influences des régimes et de leur fermentation dans le rumen sur la production de méthane par les ruminants. INRA Prod. Anim. 24:433-446.

Singer, M. D., P. H. Robinson, A. Z. M. Salem, and E. J. DePeters. 2008. Impacts of ruminal fluid modified by feeding Yucca schidigera to lactating dairy cows on in vitro gas production of $11 \mathrm{com}-$ mon dairy feedstuffs, as well as animal performance. Anim. Feed Sci. Technol. 146:242-258.

Sunvold, G. D., H. S. Hussein, G. C. Fahey Jr., N. R. Merchen, and G. A. Reinhart. 1995. In vitro fermentation of cellulose, beet pulp, citrus pulp, and citrus pectin using fecal inoculum from cats, dogs, horses, humans, and pigs and ruminal fluid from cattle. J. Anim. Sci. 73:3639-3648.

Takeoka, G., L. Dao, R. Teranishi, R. Wong, S. Flessa, L. Harden, and R. Edwards. 2000. Identification of three triterpenoids in almond hulls. J. Agric. Food Chem. 48:3437-3439.

Terry, S. A., R. S. Ribeiro, D. S. Freitas, G. D. Delarota, L. G. R. Pereira, T. R. Tomich, R. M. Maurício, and A. V. Chaves. 2016. Effects of Tithonia diversifolia on in vitro methane production and ruminal fermentation characteristics. Anim. Prod. Sci. 56:437-441. https://doi.org/10.1071/AN15560.

Tyrrell, H. F., and J. T. Reid. 1965. Prediction of the energy value of cow's milk. J. Dairy Sci. 48:1215-1223.

van Horn, H. H., S. P. Marshall, C. J. Wilcox, P. F. Randel, and J. M. Wing. 1975. Complete rations for dairy cattle. III. Evaluation of protein percent and quality, and citrus pulp-corn substitutions. J. Dairy Sci. 58:1101-1108.

Weast, R. C. 1975. Handbook of Chemistry and Physics. CRC Press, Cleveland, $\mathrm{OH}$

Wickes, R. B., and B. D. Bartsch. 1978. Dried citrus pulp or barley as energy concentrates for dairy cows. Proc. Aust. Soc. Anim. Prod. $12: 180$.

Wikandari, R., S. Gudipudi, I. Pandiyan, R. Millati, and M. J. Taherzadeh. 2013. Inhibitory effects of fruit flavors on methane production during anaerobic digestion. Bioresour. Technol. 145:188-192.

Williams, S. R. O., P. J. Moate, and M. H. Deighton. 2014a. Sampling background air. Pages 81-88 in Guidelines for Use of Sulphur Hexafluoride $\left(\mathrm{SF}_{6}\right)$ Tracer Technique to Measure Enteric Methane Emissions from Ruminants. M. G. Lambert, ed. New Zealand Agricultural Greenhouse Gas Research Centre, Palmerston North, New Zealand.

Williams, S. R. O., P. J. Moate, M. H. Deighton, M. C. Hannah, and W. J. Wales. 2014b. Methane emissions of dairy cows cannot be predicted by the concentrations of C8:0 and total C18 fatty acids in milk. Anim. Prod. Sci. 54:1757-1761.

Williams, S. R. O., P. J. Moate, M. C. Hannah, B. E. Ribaux, W. J. Wales, and R. J. Eckard. 2011. Background matters with the $\mathrm{SF}_{6}$ tracer method for estimating enteric methane emissions from dairy cows: A critical evaluation of the $\mathrm{SF}_{6}$ procedure. Anim. Feed Sci. Technol. 170:265-276.

Wing, J. M. 1975. Effect of physical form and amount of citrus pulp on utilization of complete feeds for dairy cattle. J. Dairy Sci. 58:63-66. Yalchi, T. 2011. Determination of digestibility of almond hull in sheep. Afr. J. Biotechnol. 10:3022-3026. 